\title{
The Form and Nature of 'Acceptilatio' in Classical Roman Law
}

\author{
Alan Watson \\ University of Georgia School of Law, wawatson@uga.edu
}

b

\section{Repository Citation}

Alan Watson, The Form and Nature of 'Acceptilatio' in Classical Roman Law (1961),

Available at: https://digitalcommons.law.uga.edu/fac_artchop/397

This Article is brought to you for free and open access by the Faculty Scholarship at Digital Commons @ University of Georgia School of Law. It has been accepted for inclusion in Scholarly Works by an authorized administrator of Digital Commons @ University of Georgia School of Law. Please share how you have benefited from this access For more information, please contact tstriepe@uga.edu. 


\title{
The Form and Nature of «acceptilatio» in Classical Roman Law
}

\author{
by Alan Wathon, \\ Fellow of Oriel college, Orford.
}

\section{ACCEPTEM HABERE ANI) ACEPTTM FACERE.}

Entil recently, it would seem to have been agreed among Romanists that in early classical Roman law only one form of words, namely "Habesne aceeptum ? habeo" was permitted for a valid acceptilatio, but that by the time of Clpian a second form (and no more), namely "foreptum facis? facio " had been accepted (1). Indeed, that this was the position is accepted without discussion by Mr. Nicholas in a very thorough article on the form of the stipulation $\left({ }^{2}\right)$. Mr. Nicholas' main goal is to show that in classical law stipulatio was a formal act and required to be made in one of six possible forms. In support of this, he stresses the importance of formal words in ritual acts in Roman law and after dealing with other acts which require formal words he goes on $(3)$ :

" Iore important, however, is the parallel, already mentioned, of acceptilatio. For this is intimately connected with the stipulation, of which it is, indeed, the contrarius actus. For acceptilatio Gaius admits only one formula which is given also by Ipian in the Ingest, with the addition that a second is also admissible... The form of acceptilatio was apparently never altered by legislation for Justinian in the Institutes reproduces Gaius, with lapinian's addition as to Greek."

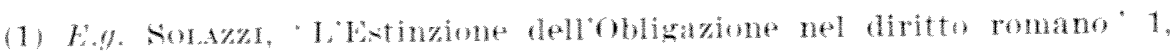

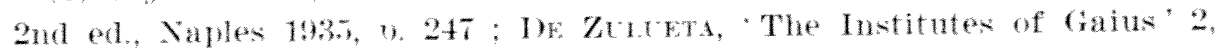
Oxford $1953,1,1 \times 9$.

(2) "The Stipulation in Roman Iaw", 19,3, I.Q.R. 1. 63 et seq.

(3) Op. rit., p. (6). 
Perhaps the case of acceptilatio is even more fundamental for Mr. Nicholas than he himself admits, since it, alone of the institutions mentioned by him in support of his argument that the stipulation required formal words is, like stipulation, without doubt iuris gentium $\left({ }^{4}\right)$. This is an important point. It is one thing to show that in the ius civile there are ritual acts with formal words, quite another to show that ritual acts with formal words occur also in that part of Roman law which was open to peregrines. After all, the main purpose of the introduction of the ius gentium was to facilitate foreign trade and to protect peregrini and it is accepted that this is best accomplished by making the law as simple as possible (5).

But the contrary opinion, that acceptilatio did not require formal words, is suggested, to my knowledge, by Dr. Winkler

(4) Contra Solazzr : see infra pp. 405-407.

(5) The other institutions which Mr. Nicholas names are: mancipatio, in iure cessio, institution of an heres, appointment of tutor testamentarius, exheredatio, cretio, the creation of the various types of legacy, appointment of a cognitor, and the creation of dos by dotis dictio. Of these all except the last two are certainly ritual acts and iuris civilis. Probably a peregrine could appoint a cognitor, but how formal the institution was and whether ritual words were required is doubtful. C. 4.93 tells us that the cognitor was substitued for the dominus c cum... certis et $q u a s i$ solemnibus verbis $\triangleright$, while Ulpian in F.V. 318 has "Non tamen sic putat certis verbis cognitorem dari debere, ut si quid fuisset adiectum vel detractum, non valeat datio, ut in legis actionibus ". Nothing more may be meant than that a certain form of words was customary, as is commonly the case in court proceedings. Moreover, even if the institution were a semi-ritual act, it would not affect the present argument to any great extent since the words would be spoken in the presence of a judicial officer who would correct any error at once, and so a peregrine would be adequately protected. The evidence that dotis dictio required formal words is even weaker (Gai Epit. $2.9 .3,4$; C.Th. 3.13 .4 ; G. 3.95 ; Lib. Sing. Reg. 6.1 .2 ; D. 23.3 .25 ; h.t. 44.1 ; h.t. 46.1). Buckland, who like others, maintains that dotis dictio was ritual has to use very sophisticated and unconvincing arguments to make it fit into his obviously correct concept of ritual acts ; "Ritual Acts and Formal Words", Festschrift Koschaker 1, p. 16 et seq. at pp. 24-25. Nor is it clear that a peregrine could create dos by dotis dictio. The only person who could make dotis dictio who might in practice (if it were permitted) be a peregrine would be the bride's debtor. 
alone, in an artirle in which she attacks Mr. Nicholas thesis $\left({ }^{6}\right.$, She submits that it is at least possible to hold this opposite view and that Gaius in a short treatment of aceptilatio need only, for teaching purposes, give one example of how it was carried out and that the fuller treatment in the Digest shows arceptilationes were in the form of question and answer but no mores, as is seen from 1). 46.4.6,7. Moreover, she says, the use of Greek does not appear to he restricted to particular forms. These arguments, however, are rather weak and do not take into account the construction of D. 46.4.7, which probably more than any other factor has inclined modern jurists to hold that areep tilatio required formal words.

1) 46.4.7 (Clpian 5o ad Sab.) Same ef sic acceptilatio fier.i potest : 'accepta facis decem ?' ille respondit 'facio'.

1). Winkler asks rhetorically why this form should be permitted for acceptilatio but others excluded (7). But this does not take us very far since the text by its insistence that this form could be used is very good evidence that it had once, and probably recently, been excluded. And, on the general view, the reason for the exclusion of this form would be that hitherto only one form "habesne acreptum ? habeo " had been recognised. Ulpian now admits, it would be argued, a second form, but no more. On this point, Dr. Winkler does not seem to make any impression on Mr. Nicholas' case.

However, despite the foregoing, it will be maintained in the present note, 1 ) that there is a vast difference in the meaning of acceptum facere and acceptum habere. 2) that it was because of his meaning, not its form, that "arcepta facis decem? facio " did not make a valid acceptilatio until perhaps as late as Iipian, 3) that its acceptance at that time is very good evidence that aceptilatio did not need formal words, and t) that other evidence is available tending to the same conclusion.

(6) "Gains $3.92 \%, 5$, R.I.D.A. (3rd ser.), 1958, p. 603 et sog., especially 1). $619-620$.

(7) Op. cit., \%. 620, n. 50. 
To take acceptum facere first. There can be not the slightest doubt that in legal Latin the expression is technical and means always "To make an acceptilatio". Excluding for the moment D. 46.4.7 which is the text in which we are interested, there are 47 juristic texts which use acceptum facere in that sense and not one which can bear any other meaning $\left({ }^{8}\right)$. It therefore seems a safe assumption that in D. 46.4.7 the only meaning which can be given to "Accepta facis decem ? facio" is "Do you make acceptilatio of the ten ?" "I do ". Pliny the Younger also uses the term in that way.

Ep. 4.2. Ad quod te ne verbis magis quam rebus horter, quidquid mihi pater tuus debuit, acceptum tibi fieri iubeo.

Perhaps because acceptum facere had among lawyers acquired a technical meaning it is found nowhere else in lay Latin except in Pliny the Elder who, however, does use is differently $\left({ }^{9}\right)$.

But the texts, lay and legal, show that acceptum habere had a very different meaning.

Livy 6.9.12. Sutrio recepto restituoque sociis Nepete exercitus ductus, quod per deditionem acceptum iam totum Etrusci habebant.

Here "acceptum... habebant" means simply "they had received". So acceptum habere would mean "to have received".

The only other non-legal texts which we have use acceptum habere in the same way.

(8) It would be pointless to give examples which would prove only that acceptum facere could be so used (which no one doubts) and it would take too much space to quote all the texts. Here, however, is a list of the texts. Labeo; D. 28.7 .20 pr. ; $46.3 .91 ; 46.4 .23$ : Javolenus ; $12.4 .10 ; 19.2 .21$; 24.3 .66 .6 : Celsus ; 46.3.71.2 : Julian ; $18.4 .19 ; 18.5 .5$ pr. ; $23.3 .49 ; 30.81 .5$; $30.82 .5 ; 30.84 .7 ; 34.3 .10 ; 39.5 .2 .3 ; 45.1 .56 .8 ; 46.7 .14$ pr. : Pomponfus ; $46.3 .80 ; 46.4 .10$ : Africanus ; 39.6 .24 : Gaius ; 4.2.10.1;46.4.22; G. 3.171 , 172,215 : Venuleius ; 1 . 42.8 .25 pr. ; 46.4.21 : Florentinus ; 46.4.18.1 : C1pian ; $4.2 .9 .7 ; 4.2 .14 \mathrm{pr}, 3,9 ; 17.1 .10 .13 ; 23.3 .36 ; 32.3$ pr. : 42.8 .10 .14 ; 44.4.7.1; 46.4.8.3,4; 46.4.13.6,9,10,12: Paul 23.4.12.2 : $46.3 .10 ; 46.4 .11 .1$ : J. 3.29 .1 .

(9) Hist. Nat. $8.61 ; 28.10 ; 34.139,142$. 
curtius 4.1.1s. Admiratus Hephaestion magnitudinem animi spernentis, quod alii per ignes ferrumque peterent, "Vos quidem macte virtute " inquit "estote, qui primi intel. lexistis, quanto maius esset regnum fastidire quam aceipere. Ceterum date aliquem regiate stirpis, qui meminerit a vobis acceptum habere se regnum n.

vulg. Tob. 12.5. Et vocantes eum, pater scilicet, ef filins, tulerunt eum in partem: ef rogare coeperunt ut dignaretur dimidiam partem omnium, quae attulerant, acceptam habere.

The legal texts tell the same story. Never do we find acceptum habere used to signify that an aceeptilatio has taken place, but the phrase always gives or expresses the words used in the making of the acceptilatio.

G. 3.169. Item per acceptilationem tollitur obligatio. acceptilatio autem est relut imaginaria solutio. quod enim ex rerborum obligatione tibi debeam, in si velis mihi remittere, poterit sic fieri, ut patiaris haec verba me dicere: QUOD EGO TIBI PROMISI, IABESNE ACCEPTUM? et tu respondeas: IIABEO.

1). 46.t.15. (Pomponius $2 \gamma$ ad Sab.) si is qui stichum promisit ita interroget: "quod stichum promisi, stichum et Pamphilum habesne acceptos ?'. puto recte accepto latum et pro supervacuo Pamphili mentionem factam, quemadmodum $s i$ is qui decem promisit ita interroget: "quod tibi decem promisi, viginti habesue accepta "', etiam decem nomine erit liberatus.

1). 46.4.6. (Tlpian ir ad sab.) Pluribus stipulationibus factis si promissor ita accepto rogasset : "quod ego tibi promisi, habesne acceptum ?', si quidem apparet, quid actum est, id solum per acceptilationem sublatum est : si non apparet, ommes stipulatiomes solutae sunt : ......

1). 46.4.9. (Panl 12 ad Sab.) Pars stipulationis aceepto fieri potest non tantum, si sie dicat: 'ex nummis decem, quos tibi promisi, quinque habesne aceptos?' sed et si sic : "quod ego tibi promisi, id pro parte dimidia habesne accep" tum ?'. 
The relevant formula is given by Florentinus ( 8 Inst.) in D. 46.4.18.1 and shows the same usage.

"Quod Numerius Negidius Aulo Agerio promisit spopondit, id haberetne a se acceptum, Numerius Negidius Aulum Agerium rogavit, Aulus Agerins Numerio Negidio acceptum fecit."

Nowhere do the respective meanings of habere acceptum and facere acceptum appear more clearly. "Id haberetne a se acceptum ... rogavit" can only mean " He asked if he had received it from him ". A translation such as " He asked if he had made acceptilatio from him " would be absurd. Apart from other considerations, it is excluded by the words " $a s e$ ». On the other hand "acceptum fecit" can mean only " he made acceptilatio". It is quite impossible to translate it as " he accepted it ", firstly because in fact he received nothing, and secondly, if it were meant to express the words used by Aulus Agerius in reply to Numerius Negidius it would be dependent on a verb such as ' ait' and be in the subjunctive.

Accordingly, legal as well as lay usage shows that acceptum habere always meant " to have received", never " to make acceptilation. If it could have borne the latter meaning we would, without debt, have found texts where the expression was used to indicate that acceptilatio had taken place. And this interpretation of the meaning is borne out by the history of acceptilatio. Acceptilatio was the contrarius actus of the stipulatio and originally mere performance did not release the debtor. Acceptilatio at that time accompanied the payment and was necessary for the extinction of the debt. The words, therefore, testified to a real payment. And considering the archaic nature of "acceptum habesne? habeo" there can be little doubt that this form goes back to that period, where it must have meant "Have you received?" "I have".

Thus, to sum up so far : "acceptum facere" means " to make an acceptilatio": and "acceptum habere" means "to have received n.

There is therefore, a great difference between the meanings of the phrases "Accepta habes decem ? habeo" and "Accepta facis 
decen? facion. In the first, on the face of it there had been a payment, in the second clearly there has been no payment. And I submit that it was because the latter showed that no payment had been malle that it was so long excluded from acting as a release. As in stipulation the words used rather than the intent of the parties were of primary importance. While in "acesp tum habesne? habeon it did not affect the validity of the release that there had been no payment but merely a pretence of such of which everyone was aware, a failure to pretend vitiated the release. Where the law recognises and acts on a fiction in the dealings of individuals, the truth shoud not appear ex facie the words or writs which form the basis of the fiction. Therefore, Gaius tells us right at the beginning of his account of acceptilatio in the Institutes 3.169 that it was a sort of imaginary payment. Even in modern law where a fiction is recognised, the true position must not appear ex facie. Scotland provides a good example of this.

Inder scots law, it is theoretically impossible to transfer land in security, although often it would be useful to do so. Scottish conveyancers have therefore devised a way round the prohibition. The normal document (called a Disposition) which transfers land and which must be registered begins: "I, A.B., in consideration of the sum of $\mathfrak{E}$-, of which I acknowledge the receipt do hereby sell and dispone to C.D. heritably and irredeemably all and whole that plot of ground... ". Where, however, (.I). makes an advance to A.B. and wants the property to be transferred to him as security, the Disposition runs: ( I, A.B., in consideration of certain good and onerous causes and considerations do hereby sell and dispose to C.D. heritably and irredeemably all and whole that plot of ground... ". The Disposition is then registered and the debtor is protected by another document which relates the true state of affairs but is not registered. Every Scottish law student and practitioner knows that when he sees "for certain good and onerous causes and considerations " he is dealing with a security although the document purports otherwise. Indeed, even the Inland Revenue authorities do not demand the stamp duty which would be payable on an out and out transfer. Nerertheless, the general 
knowledge of the true intent of the parties, which is contrary to the law, does not affect the validity of the transfer. If, however, the parties with the same intention allowed it to appear on the face of the deed which was to be registered, they would achieve nothing. Thus, a Disposition beginning : “I, A.B., in consideration of an advance of $E$ - of which $I$ acknowledge the receipt do hereby dispone to C.D. all and whole that plot of ground..." would be refused registration.

Moreover, the extension permitting "facisne acceptum? facio " to constitute a valid acceptilatio is very strong evidence that acceptilatio did not require formal words in classical law. The difference in meaning from the form \& habesne acceptum ? habeo" is too great for it to be accepted as the first alternative. Rather, an alternative form, having approximately the same meaning, e.g. "dedine? dedisti" would have been introduced. The acceptance of "acceptum facisne? facio" shows not a relaxation of form but that the concept of acceptilatio was undergoing considerable modification by the time of Ulpian and that its fictitious nature was ceasing to have any importance $\left({ }^{10}\right)$. The retention of "habesne acceptum ? habeo " as the main form would be due to legal conservatism.

There are also other arguments that acceptilatio was informal. First, Greek was allowed provided the acceptilatio were made as it would have been if Latin had been used.

D. 46.4.8.4 (Ulpian 48 ad $S a b$.$) ... et ideo puto et Graece$ posse acceptum fieri, dummodo sic fiat, ut in Latinis verbis

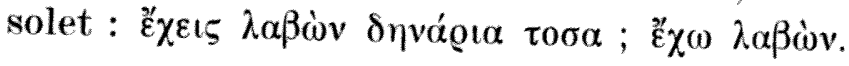

Ulpian, not Papinian as Nicholas says $\left({ }^{11}\right)$, tells us he thinks Greek can be used, and he gives a form of acceptilatio in Greek. It would be straining commonsense to assert that this form were

(10) a Sane et sic o in D. 46.4 .7 make it probable that the modification was generally accepted in the time of Ulpian and that he was not responsible. For the brenkdown of the fiction of performance see infra, pp.
407 et seq.

(11) Op. eit., p. 69 . 
he only one possible beatuse it alone is giren here since we now that lopian himself wonld, at the rery least, allow two orms in Latin. And the very fact that creek was permitted is strong argument against the view that arepeptilatio required ormal works. Where ritual words are needed, translations are ot usually permitted. Thus there is not the slightest evidence hat Greek was ever allowed in manripatio and in iure ressio and there is a very strong presumption against its use, while we znow that a mancipatory will could not be written in Greek intil 439) A.I). (12).

Secondly, since Justinian's Institutes reproduce Gaius with the addition as to Greek, and there was, so far as we know, no legislation, Mr. Nicholas holds $\left({ }^{13}\right.$ ) that areeptilatio remained formal in the time of Justinian. This is fored upon him because it would be illogical to hold that Gaius account showed that acceptilatio was formal, while the same account in Justinian dealt with informal release. But it is most unlikely that accep tilatio was formal in the time of Justinian. If it were, it would be the sole remaining ritual act which required formal words. It is much more probable that Iustinian is giving merely an example and at that the most common $\left({ }^{14}\right)$. And if one holds that arceptilatio were informal in the time of Justinian, then there is no evidence whaterel that Gains took any other view.

\section{CONTRARILS ACTLS.}

The complex nature of areptilatio in elassical law derives from two factors: first, it began as the contrarius actus of the stipulation, but sometime during the Republic ceased to be so ; secondly, therempon. it continued to act as a release under the fiction that the obligation hat been performed.

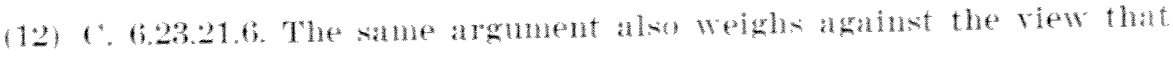
stipulatio realubed formal works.

(13) Lore rit.

(14) Again remember legal comservation. In the case of stipulation, the oldest form apondesne? spondcom ocaurs several times more frequently than all the other axamples adled togethex. 
From its original connection with stipulatio it retains during classical and Justinianic law a number of rules, none of which ever seems to have been greatly weakened.

The first of these is that there can be no conditional acceptilatio $\left({ }^{15}\right)$. Naturally if the original scope of acceptilatio was to terminate a rerbal obligation when there had been performance and to provide evidence of this, no dies or condicio could be possible. Likewise, of course, this would mean that orginally there could be no such thing as a partial acceptilatio. And we have evidence that this was the case, although in this respect acceptilatio does show signs of development.

G. 3.172. Item, quod debetur, pro parte recte solvitur ; an autem in partem acceptilatio fieri possit, quaesitum est.

So, in the time of Gaius, an attempt was being made to permit a partial acceptilatio but this had not yet prevailed. But other texts show that eventually the innovation was completely accepted $\left({ }^{16}\right)$.

D. 46.4.10. (Pomponius 26 ad $s a b$.) Sed et si non numerata pecunia, sed certum corpus, veluti homo in stipulationem deductus est, potest ex parte acceptilatio fieri : quo modo et uni ex heredibus acceptum fieri potest.

D. 46.4.13.1. (Ulpian 50 ad $S a b$.) Si id, quod in stipulationem deductum est, divisionem non recipiat, acceptilatio in partem nullius erit momenti, ut puta si servitus fuit praedii rustici vel urbani ......

D. 46.4.9 (Paul 12 ad Sab.) This is quoted supra p. 395.

The second such rule is that only verbal obligations can be so extinguished. Any other obligation had first to be turned into a stipulation.

G. 3.170. Quo genere, ut diximus, tolluntur illae obligationes quae in rerbis consistunt, non etiam ceterae. consen-

(15) D. 46.4.4 (Pomponius 9 ad sab.) ; h.t.5 (Clpian 34 ad Sab.).

(16) D. 46.4 .17 (Jullan 54 dig.) is probably interpolated. Cf. Solazzi, op. cit., p. 25, Index Itp. 
taneum visum est repbis factam obligationem posse aliis verbis dissolvi. sed id quod ex alia causa debeatur potest in stipulationem deduci et per acceptilationem dissolvi.

This rule remained unchanged in the law of Justinian (17).

The third rule which acceptilatio owes to its origins is that just as there could be no stipulatio alteri, so one could not make acceptilatio on behalf of a person not in one's potestas. But whereas in the case of stipulation there was some relaxation in the law of Justinian (18) there is no sign of any in accep. tilatio.

1. 46.4.3. (Paul \& ad Sab.) Per procuratorem nec liberari nec liberare quisquam acceptilatione sine mandato potest.

There is general agreement that sine mandato is a Justinianic interpolation $\left({ }^{19}\right)$, and the interpolation is clearly shown by a text of Ulpian (.50 ad Sab.).

D. 46.4.13.10. Tutor, curator furiosi acceptum ferre non potuit, nec procurator quidem potest facere acceptum : sed hi omnes debent novare (possunt enim) et sic accepto facere. ne his quidem accepto fieri potest, sed novatione facta poterunt liberari per acceptilationem. nam et in absentium persona hoc remedio uti solemus: stipulamur ab aliquo id novandi causa, quod nobis absens debet, et ita accepto liberamus, a quo stipulati sumus : ita fiet, ut absens novatione, praesens acceptilatione liberetur.

Solazzi argues correctly $\left({ }^{20}\right)$ that the former of these texts does not in Justinianic law free the procurator from the necessity of proceeding to an acceptilatio by way of novatio. Sine mandato has been added by Tribonian who demands that the procurator should have a special mandate before he has the power to make novatio. It is one example of the Justinianic restrictions on the powers of the procurator.

(17) D. 46.4.8.3 (Llyian 48 ad sab.) ; J. 3.29.1.

(18) E.g. D. 45.1.38.22; J. 3.19.19,20,

(19) Cf. Index Itp. : Serrao, 'Il Procurator', Milan 1947, p. 36.

(20) Op. cit., p. 251. 
D. 46.4.8.4. (Ulpian 48 ad Sab.) Filius familias promittendo patrem civiliter non obligat, sed se obligat: propter quod accepto rogare filius familias potest, ut se liberet, quia ipse obligatus est, pater autem acceptum rogando nihil agit, cum non sit ipse obligatus, sed filius. idem erit et in servo dicendum : nam et servus accepto liberari potest, et tolluntur etiam honorariae obligationes, si quae sunt adversus dominum. quia hoc iure utimur, ut iuris gentium sit acceptilatio : (21)

This text shows the full force of the doctrine. Where a filiusfamilias enters into a contract he himself is fully liable $\left({ }^{22}\right)$, but the paterfamilias is not unless (and only on the extent that) one of the actiones adiecticiae qualitatis is available. Thus, the liability of the pater is purely subordinate and differs therefore from the liability of a fideiussor. Since the pater is not subject to the potestas of the filius, he cannot, we are told, make a valid acceptilatio to release a debt incurred by his filius. The text then goes on to say that the same applies where a slave is liable under a stipulation, although here, of course, there is only a naturalis obligatio. But when the slave himself is released by acceptilatio this wipes out even the master's praetorian obligations. Conversely, just as one could acquire through the stipulation of a slave in whom one had a usufruct $\left({ }^{23}\right)$ so an acceptilatio could be made to a servus fructuarius which would release the usufructuary.

D. 7.1.23 pr. (Ulpian $1 \%$ ad Sab.) Sed sicuti stipulando fructuario adquirit, ita etiam paciscendo eum adquirere exceptionem Iulianus libro trigensimo $\left({ }^{24}\right)$ digestorum scribit. idemque et si acceptum rogaverit, liberationem ei parere.

(21) 'Civiliter" would seem to be interpolated; $c f$. Index Itp. for other suggested interpolations, see infra, pp. 406-407.

(22) Cf. Solazzr, 'Sulla Capacità del filius familias di stare in giudizio , Seritti 1, pp. 1 et seq.

(23) E.g. G. 2.91 ; D. 7.1 .24 .

(24) It should read 35 . Cf. F.V. 72.i. ; D. 2.14 .55$. 
Again, there is the rule that a slave cannot release his master's debtor by acceptilatio even at his owner's request.

D. 46.4.2.2 (Gaius 3 de rerborum obligationibus) Servus nec inssu domini acceptum facere potest.

This stems from the ancient principle that a slave can do nothing to injure his master $\left({ }^{25}\right)$. Just as originally the slave could make a valid stipulation the benefits of which would accrue to his master while he could not bind his master by stipulation $\left({ }^{26}\right)$, so he could release his master by making an arceptilatio on his behalf $\left({ }^{27}\right)$ but could not release his master's debtor. Solazzi denies this reason $\left({ }^{28}\right)$, and says that the slave's incapacity is purely on the ground of form. The reply "Habeo acceptum ", he says, to be effective, must come from the creditor. But why, from the point of view of form, should it? A payment of a debt due to the master, if made to the slave with the master's consent would, of course, like such a payment to anyone else, release the debtor. Therefore, considering acceptilatio from the point of view of form, there is no reason why a slave's acknowledgement that he has received the sum due to his master should not likewise effect the release.

What is perhaps a slightly more conjectural instance of the influence that stipulatio continued to have over acceptilatio is in G. 3.171 .

Quamvis autem fiat acceptilatio imaginaria solutione, tamen mulier sine tutore auctore acceptilationem facere non potest, cum alioquin solvi ei sine tutore auctore possit. Almost nothing is known of the rights and duties of the tutor mulieris in early law, but Bonfante tells us that the history of

(25) This, the common formulation, is rather too wide: fof Buckiaxn, "The Roman Law of Slavery ", Cambridge 1907, 1. $16 * 3$.

(26) The better view would also seem to be that while a slave conld receive by mancipatio he could not so deliver: of. MITters, a Römisches Privatrecht n, Leipzig 1908, p. 208 and n. 16 ; contra, Buckiaxn, op. eit, p. 150 .

(27) $C f .1), 46.4 .8 .1,2 ; 11 \mathrm{pr} . ; 1,2,3$.

(28) "L'Fstinzione" cit., p. 250. 
tutela mulieris is the history of its dissolution $\left.{ }^{29}\right)$. Accepting Bonfantes view (and few would quarrel with it), perhaps the rules expressed in 'xaius' text developed in the following way. clearly the motive behind tutela mulieris was to protect the woman's property for the benefit of the person who would become heir on her death and this person would normally himself be the tutor. Accordingly, the woman was not allowed to do anything which might diminish her patrimony without her tutor's consent. Therefore, without his authority she conld not release a rerbal obligation i.e. by acceptilatio. Probably, like a pupil in classical law $\left.{ }^{30}\right)$, she could receive payment of a debt and the money became hers although the debtor was not released. But eventually with the breakdown of the requirement of contrarius actus and the weakening of the position of the tutor mulieris it was admitted that payment to her, without her tutor's consent of a debt due under stipulation released the debtor without any further ado. At the same time however, she was not allowed to grant acceptilatio since it, being now a fictitious payment would result in a definite loss to her patrimony. And this rule, as a result of Roman conservation, was not altered in classical law $\left({ }^{31}\right)$.

Perhaps some of the foregoing will seem self-apparent, but it is nevertheless important to remember that many of the rules of acceptilatio have their origin in its connection with stipulation. Otherwise it is only too easy to draw false conclusions as to the nature of acceptilatio.

(29) "Corso di diritto romano" 1. Diritto di Famiglia. Rome 1925, 1. 409 .

(30) Cf. G. 2.84.

(31) DE Zulceta, op. cit. 2 p. 189 attributes it to acceptilatio being originally an actus logitimus. But on the ground of formalism it is difficult to see why the act of a woman should be invalid unless accompanied by the tutor's consent which, strictly speaking, is not part of the act. In respect of the disabilities of women a distinction should be drawn between cases where the woman lacks capacity, even with the consent of the tutor, and cases where she can act provided she has such authority e.g. accotilatio, mancipatio or in making a will. In the latter category all the acts are such as could either result in a loss to her patrimony or at least weaken the right of the tutor legitimus to it. 
The awareness that acceptilatio had been the contrarius actus of stipulatio would seem to have been blurred as early as Gaius otherwise it is difficult to account for his weak reason for acceptilatio being available to release verbal obligations only ( $\left.{ }^{32}\right)$. And for later jurists matters were made even more complicated by Papinian including it among actus legitimi " qui non recipiunt diem rel condicionem " $\left({ }^{33}\right)$. The meaning of actus legitimus, which occur's only in this text is doubtful. It may signify nothing more than 'a legal institution which cannot be made subject to a condition'; and indeed, legitimi may even be an interpolation $\left({ }^{34}\right)$. But actus legitimi are now, without any real evidence, taken to mean solemn transactions originating in the old mos maiorum and so false conclusions about the original nature of acceptilatio are drawn $\left({ }^{35}\right)$. It is of course true that acceptilatio could not be conditional but this, as we have seen, was because it was, to begin with, a release from a verbal obligation. This also explains why a partial acceptilatio was at first impossible although it would be difficult to account for this on the ground that it was a formal act in the law.

Probably Solazzi $\left({ }^{36}\right)$ more than anyone else was led astray by failing to give proper weight to the importance of the original purpose of acceptilatio. For instance, basing himself to a great extent on the texts cited above in this connection, he maintains that even in classical law acceptilatio was not iuris gentium. The steps in his argument are as follows. First, he says that D. 46.3 .107 (Pomponius 2 enchiriddi) of which he luotes part only, denies that acceptilatio was iuris gentium.

(32) G. 3.170. Cf. supra, p. 400. Cf. Pomponius D. 46.3.80.

(33) 19.70 .17 .77 .

(34) $C f$. Index Itp.

(35) E.g. Aravgro-Ruiz, 'Istituzioni di diritto romani', 14th, ed, Naples, ). 86 ; BCckiand, 'Textbook of Roman Law', 2nd ed., Cambridge, 1932, 1. $180, n$. 1. Fven a shrewd observer like De Zulneta could write a Like tipulatio it was iuris gentium, but it retained characteristics that show $t$ to have once been an actus legitimus n, loc. cit. This does not even gree with Pomponius who says that it is an actus legitimus. Perhans ke stipulation acceptilatio was at the beginning restricted to one form, ut this need not make it a very formal act. Cf. supra, p. 404, n. 31 .

(36) "L'Fstinzione " cit, 10,247 ot seq. 
Verborum obligatio aut naturaliter resolvitur aut civiliter : naturaliter veluti solutione aut cum res in stipulationem deducta sine culpa promissoris in rebus humanis esse desiit : civiliter veluti acceptilatione vel cum in eandem personam ius stipulantis promitentisque devenit.

But the contrast is not as he would have it between release by matter of fact and release by operation of the ius civile. If it were, since Pomponius is contrasting all the genera of release of a verbal obligation (this follows from "Verborum obligatio aut naturaliter resolvitur aut civiliter") we would have to hold that stipulation could not be released by any praetorian mode, which would be odd in the case of a iuris gentium obligation. Especially, we should have to hold that confusio of a verbal obligation is also iuris civilis $\left({ }^{37}\right)$. Here ciriliter means not " by operation of the ius civile " but, as elsewhere, simply "by operation of law ") $\left({ }^{38}\right)$.

He then turns to $\mathrm{D}$. 46.4.8.4 $\left({ }^{39}\right)$ in which he admits that civiliter is interpolated $\left({ }^{40}\right)$. He then declares that the text is also interpolated from "idem erit et in servo dicendum" because if for the slave the same principles operated as for the son of whom it is said that he can make an acceptilatio "quia ipse obligatus est " neither the slave nor his master could make an acceptilatio. What he is really saying is that although civiliter is interpolated, the son can release himself by acceptilatio because he is bound iure civile, whereas his pater cannot since he is only liable iure gentium, and therefore since the slave is not liable iure civili he cannot release himself by acceptilatio.

(37) Accordingly so concluded by Solazzi, op. cit., 1. 279. On the same page $n .1$ he declares that the distinction drawn by Pomponius between extinction naturaliter and civiliter is valid not only for verborum obligatio but for all obligations. Yet elsewhere he admits that there could be compensatio even of naturales obligationes at least in the actiones bonae fidei. "La Compenzatione nel diritto romano ", 2nd ed., Naples 1950, p. 7 .

(38) Civiliter is also used to signify that an obligatio is simply actionable as opposed to a natural obligation. Cf. I. $41.1 .53 ; 41.2 .24 ; 44.7 .14$; 45.1.1.2 ; 46.2.1.1 (where "an honoraria" is a gloss : cf. Index Itp.).

(39) Quoted supra, p. 398.

(40) "L'Estinzione" cit, p. 248, n. 1. 
But we have seen that the reason for the rule in both cases is that the primary debtor is the son or slave while the obligation of the pater or dominus is purely subsidiary and since the latter, naturally, are not in the potestas of the former they cannot release them by aceptilatio. There are no traces of interpolation in the text $\left({ }^{41}\right)$.

\section{TILE BREAKDOWN OF THE FICTION.}

The second great factor in the nature of acceptilatio was its character as a fictional payment. When it ceased to be required as the contrarius actus of a verbal obligation which had been fulfilled it found this new function. No doubt for some time after it was no longer essential to release a stipulation ${ }^{42}$ ) it would still be used where payment had been made and would retain all the characteristics it had when it was required, but eventually would be used only where there had been no performance. Probably, at this point it would be a complete fiction. Not much later, however, the jurists would begin to destroy its fictional character bit by bit. A fiction of this type cannot retain its purety long. When this process began we cannot say, nor can we trace its history to any great extent. Indeed, although in some cases we can show a change in juristic attitude between early and late classical law, in those cases in which we might expect the fiction to break down quickest we have no early authority.

Perhaps the first attacks on the fiction would be in the spheres of release in fraud of creditors and of donations between husland and wife.

(11) The order of the text at the end may be disarranged: $c f$. Index Ity. ; but this is not necessarily so. Honorariae obligationes and not honorariac actiones should not in itself be susplicious in the time of Clpian, since obligatio often by then dil refer to a praetorian obligation: of. SEcke, studi Bonfante 3, 1. 601, who, however, on 1. 599 holds that there is a post-classical and Byzantine tendency to use obligationcs lomorariae. See the works ated by him op. cit, 1. $509, \mathrm{n} .291$.

(42) When this was cannot be stated, but it was certainly during the Republic. Cf. LÉr-Bron, 'Te denxime chapitre de la lot Aquilia'. R.I.D.A. (3rd Ser.), 5, 1958, p. 507 et seq. 
For the former, howerer, we have only the testimony of Ulpian.

D. 42.8.1.2. (Ulpian 66 ad ed.) Ait ergo praetor 'quae fraudationis causa gesta erunt'. haec verba generalia sunt et continent in se omnem omnino in fraulem factam vel alienationem vel quemcumque contractum. quodeumque igitur fraudis causa factum est, videtur his verbis revocari, qualecumque fuerit: nam late ista rerba patent. sive ergo rem alienavit sive acceptilatione vel pacto aliquem liberavit.

D. 42.8.10.14. (Ulpian 63 ad ed.) Si, cum mulier fraudandorum creditorum consilium inisset, marito suo eidemque debitori in frauden creditorum acceptum debitum fecerit dotis constituendae causa, locum habet haec actio et per hanc omnis pecunia, quam maritus debuerat, exigitur nec mulier de dote habet actionem $\left({ }^{43}\right) \ldots .$.

Both texts have been interpolated but not in any way which would diminish their value for us $\left.{ }^{(44}\right)$. They both show quite clearly that it is accepted by Ilpian at least that the court will take notice of the fact that really there has been no payment.

For the breakdown of the fiction in donatio inter rirum et uxorem we have evidence as early as Julian.

D. 24.1.5.1. (Ulpian 32 ad Sab.) Si maritus duos reos habeat Titium et mulierem et mulieri accepto tulerit donationis causa, neuter liberatur, quia acceptilatio non valet: et haec Iulianus libro septimo decimo digestorum scribit. plane si mihi proponas Titio acceptum latum, ipse quidem liberabitur, mulier vero manebit obligata (45).

But although for neither of the above situations have we evidence that the fiction broke down early, we have such evidence in other cases.

D. $28.7 .20 \mathrm{pr}$. (Labeo 2 post. a Iatoleno epit.) Mulier, quae viro suo ex dote promissam pecuniam debebat, virum here-

(43) Cf. D. 18.4.2.5.

(4) $C f$. Index Itp.

(45) ('f. D. 24.1.32.23. 
dem ita instituerat, si eam pecuniam quam doti promisisset, neque petisset neque exegisset. puto, si vir denuntiasset ceteris heredibus per se non stare, quo minus acceptum faceret id quod ex dote sibi deberetur, statim eum heredem futurum. quod si solus heres institutus esset in tali condicione, nihilo minus puto statim eum heredem futurum, quia ábúvatos condicio pro non scripto accipienda est.

Thus, were a wife constitued a dowry by dotis dictio (46) which was never paid and left her husband her heir on condition that he neither sued for nor exacted the dowry, it was held as early as Labeo (or perhaps Javolenus) that if the husband were prepared to make acceptilatio to his co-heirs he would become heir immediately. This relaxation of the fiction might have become necessary as the only way in which the husband could take his share of the inheritance. A pactum de non petendo might not at first have been sufficient, although it was later $\left({ }^{47}\right)$, since the husband would still have the right to sue for the dowry although his co-heirs could meet him with an exceptio. A declaration by the husband that it was not due to him that acceptilatio was not made, though it could have only the force of a pact may have been permitted on the facts either because the co-heirs had not entered the inheritance or because they refused to make acceptilatio $\left({ }^{47}\right)$. This relaxation of the fiction is the one for which we have the earliest proof in the texts.

Javolenus is also responsible for giving us proof of the disintegration of the fiction in another field.

D. 12.4.10 (Iarolenus primo ex Plautio) Si mulier ei cui nuptura erat cum dotem dare vellet, pecuniam quae sibi debebatur acceptam fecit neque nuptiae insecutae sunt, recte ab eo pecunia condicetur, quia nihil interest, utrum ex numeratione pecunia ad eum sine causa an per acceptilationem pervenerit.

A woman by way of dowry releases by acceptilatio a debt owed to her by her future husband. The marriage does not take place

(46) $(* f$. Index Itp.

(47) $C f, 10,35.1 .7 .1$. 
and we are told that the woman has a condictio for the recovery of the sum, which could never have been the case if the acceptilatio were regarded as a true payment by the man for which the woman released him. Nerertheless, the acceptilatio extinguished the verbal obligation, otherwise Javolenus could not have said "quia nihil interest, utrum ex numeratione pecunia ad eum sine causa an per acceptilationem perenerit" $\left({ }^{48}\right)$.

The cases so far dealt with, although probably among the earliest, are unsatisfactory for us to the extent that they do not show any signs of development and might suggest that in classical law acceptilatio had lost all traces of its former position as a fiction. But that this was not the case is shown by other situations.

D. 46.4.23. (Labeo 5 pithanon a Paulo epit.) Si ego tibi acceptum feci, nihilo magis ego a te liberatus sum. PAU. LUS : immo cum locatio conductio, emptio venditio conventione facta est et nondum res intercessit, utrimque per acceptilationem, tametsi ab alterutra parte dumtaxat intercessit, liberantur obligatione.

Labeo tells us that if I release you by acceptilatio, I am not in any way released from my obligation to you. Obviously, he is thinking of obligations under a bilateral contract $\left({ }^{49}\right)$ and where neither party has performed his part of the agreement. Where there is such a bilateral, consensual contract $\left({ }^{50}\right)$ which is unperformed a release by one party would normally terminate the contract $\left({ }^{51}\right)$, but Labeo holds fast to the fiction that acceptilatio

(48) In D. 23.3.43, Clpian tells us that in the same situation Scaevola, with whom he agrees, held that the acceptilatio was void and that the original obligation remained. But the text may be interpolated: $c f$. Beseler, 45 ZSS (1025), 489 ; AmelotT, "La Donatio Mortis Causa in diritto romanon, Milan 1953, pp. 180-181.

(49) No one would suggest that if I am your debtor under a stipulation and I am left a legacy by a testator to whom you are heir, acceptiatio of the stipulatio, without anything further, would have any effect on the legacy.

(50) The contract must be consensual because only such can exist where both parties have still to perform their part of the agreement.

(51) Cf. e.g. D. 18.1.72; DCFF, 'Studies in the Roman Law of Sale dedicated to De Zulueta; ed. by Daube, Oxford 1959, pp. 69-70. 
is a payment of what is owed $\left({ }^{52}\right)$ and so the releasing party is not himself freed from his obligation. Paul, however, in the case of sale and hire, which are the situations in which this would normally operate holds that the releasing party is himself freed. For him, in this respect, acceptilatio is nothing but a release where there has been no performance. When the view accepted by Paul became current can be more closely dated since we have a text of Julian (15 dig.) putting forward the same opinion.

D. $18.5 .5 \mathrm{pr}$. Cum emptor venditori vel emptori venditor acceptum faciat, voluntas utriusque ostenditur id agentis, ut a negotio discedatur et perinde habeatur, ac si convenisset inter eos, ut neuter ab altero quicquam peteret, sed ut evidentius appareat, acceptilatio in hac causa non sua natura, sed potestate conventionis valet.

Both of these texts are widely held interpolated as to form $\left({ }^{53}\right)$, but one might have thought it difficult to dispute their substance. But this too, has been done. Perozzi held that the substance of the latter was interpolated by Justinian since in classical law acceptilatio had no effect on obligations other than verbal or literal $\left({ }^{54}\right)$. And this seems also to have been the opinion of Beseler who would reconstruct the text as follows : ' Cum emptor venditori vel emptori venditor acceptum facit, nihil agitur' $\left.{ }^{(55}\right)$. But apart from the fact that that side of the contract which is to be the object of the acceptilatio might well have been turned into a verbal obligation by an Aquilian stipulation and this has been omitted for reasons of brevity (as is certainly the case in the situation discussed by Labeo in D. 46.4.23 or the acceptilatio could never have wiped out the obligation of one party), both Perozzi and Beseler ignore the important point that the consensual contract is still integer $\left({ }^{56}\right)$.

(52) There must have been a stipulatio Aquiliana although it is not mentioned.

(53) Cf. Index Itp.

(54) 'Istituzioni di diritto romano', 2nd ed., Rome 1928, p. 403, n. 1.

(55) 47 ZSS (1927), p. 358.

(56) Cf. Rrccoboxo, 'Studi Bonfante' 1, p. 15. 
Where a consensual contract is integer and the parties change one of the essential terms, the old contract is wiped out and a new one rises in its stead $\left({ }^{57}\right)$, and where one side of the obligation is wared the contract is terminated and no new one takes its place. Hence, in an integer consensual contract even an invalid acceptilatio could have the effect of destroying the contract completely, provided one recognised that that acceptilatio was a mode of release without performance $\left({ }^{58}\right)$. Solazzi, in his turn, holds that both texts are interpolated as to substance $\left({ }^{59}\right)$. He gives the additional reason for his view that acceptilatio by the buyer of the seller attests that he has received the object. How, he asks, could such a declaration release the buyer from the obligation to pay the price. But this argument would be valid only if acceptilatio had always retained its pure character as a fictitious payment whereas it is abundantly clear that during the classical period this was lost step by step. Moreover, Solazzi fails to ask himself one fundamental question. D. 46.4.23 is a text of Labeo 5 pithamon epitomised by Paul, and on Solazzi's view one must hold that the whole substance of the section supposed to represent the view of Paul is interpolated. But Paul must have held an opinion differing from that of Labeo or he would not have bothered to discuss the point. And it is difficult to see what this could have been other than that given in the text.

We can also trace the disintegration of the fiction in the history of legatum liberationis. Legatum liberationis is not early $\left({ }^{60}\right)$, but in classical law it could be made in two main ways; either by legatum sinendi modo or by legatum per damnationem. The earliest reference to a legatum liberationis per damnationem, which is the form in which we are interested is in a text of Pomponius (6 ad $s a b$.).

(57) Cf. supra, p. 410, n. 51.

(58) This is surely what is meant by 'scd ut ctidcutius ete' whether or not it is an interpolation.

(69) Op. cit., no. $268-270$.

(60) The earliest reference is to Nerva and Atilicinus in D, 34.3.16: cf. Brondr, 'Successione Testamentaria', 2nd ed., Milan 1955, pp. 45. ot $8 e q$. 
D. $34.3 .2 \mathrm{pr}$. Heredem, damnatum a fideiussore non petere a reo petere posse, sed a reo petere vetitum, si a fideiussore petat, reo ex testamento teneri Celsus putat.

Here we are told that Celsus held that if a legatum liberationis were left per damnationem to a guarantor, the heir could not sue him but he could sue the principal debtor ; but where the legatum liberationis was to the principal debtor and the heir sued the guarantor, the principal debtor would have an actio ex testamento against the heir, i.e. because he would be liable to the fideiussor on an actio mandati. From this text, it would seem that in Celsus' view, if the legatee were sued he had an exceptio doli mali (61), and if the fideiussor were sued successfully when the legacy was to the principal debtor, the latter had an actio ex testamento for the amount of the debt.

But other jurists from the time of Julian took a different approach $\left({ }^{62}\right)$.

D. 34.3.5 pr. (Ulpian 23 ad Sab.) Si quis reum habeat et fideiussorem et reo liberationem leget, Iulianus ibidem scripsit reum per acceptilationem liberandum : alioquin si fideiussorem coeperit convenire, alia ratione reus convenitur... 1. Quod si fideiussori sit liberatio legata, sine dubio, ut et Iuliano scribit, pacto erit fideiussor liberandus...

Thus, Ulpian tells us that Julian held that where a legatum liberationis is left to the principal debtor he must be released by acceptilatio, but where the legatum is to the fideiussor only, he is to be released by pact. It might, however, be argued that the situations in the two texts are fundamentally different in

(61) It is impossible for 'petere non potest' here to mean 'he cannot bring the action" because the legatum does not extinguish the debt since otherwise the heir could not bring the action against the other debtor. This is confirmed by $\$ 1$ where we are told that Celsus likewise held that the heir of the heir cannot sue and this point would never have been raised if the legacy extinguished the debt. For the cxceptio, cf. D. $39.6 .28 ; 44.4 .17 .1 ; 34.3 .20$ pr. ; 44.4 .8 pr., 1 .

(62) It is best to leave D. 44.4 .8 pr., 1 (Paul 6 ad Plaut.) out of account since it is not clear, first, how far the decision shows any innovation and secondly, how far the decision is due to Plantius or Paul. 
that in the former the legacy was expressed 'damnas esto non petere', in the latter 'damnas esto liberare'; and that therefore the second stronger form required positive action by the heir, and this accounts for the two contrasting decisions. But that the form in which the legatum liberationis was expressed did not affect Julian's decision is shown by another text from the same book of Clpian.

D. 34.3.7.1. Si is qui stipulatus stichum aut decem damnaverit heredem stichum non petere, legatum valere constat: sed quid contineat, videamus. et Iulianus scribit actionem ex testamento in hoc esse videri, ut debitor accepto liberetur : quae res utique debitorem et in decem liberabit, quia acceptilatio solutioni comparatur, et quemadmodum, si Stichum solvisset, debitor liberaretur, ita et acceptilatione Stichi liberari.

Here the legacy, as in $0.34 .3 .2 \mathrm{pr}$. is expressed 'damnas esto non petere' yet Julian says that acceptilatio must be made. This text brings out a vital point which is not clear in D. $34.3 .5 \mathrm{pr}$., namely, that the actio ex testamento lies to compel the heir to free the debtor by acceptilatio. This is obviously a big advance from the time of Celsus where it would seem that the debtor had only the right to an exceptio if sued or an actio ex testamento where the debt was paid. It shows a complete breakdown of the fiction that acceptilatio was a release on performance when a creditor who is under an obligation not to accept the debt can be judicially ordered to release the debtor by acceptilatio $\left.{ }^{63}\right)$.

Also probably not very early is the relaxation which permits an acceptilatio which is made mortis causa to be treated in all respects as a donatio mortis causa; hence it may be revoked if the donor recovers and it is treated as part of the inheritance for the purposes of the lex Falcidia. Since the earliest texts we have are one from Africanus $\left({ }^{64}\right)$ and two from Gaius ( ${ }^{65}$ ) in

(63) For other texts on acceptilatio in this connection see D. 34.3.3.3 ;

h.t. 10 ; h.t. 29 ; 38.2 .50 .6 ; 35.2 .82 ; C. 6.42 .17 ; J. 2.20 .13 .

(64) D. 39.6.24.

(65) D. 39.6.31.1,4. 
one of which he refers with approval to Julian, it is possible that the breakdown of the fiction here does not go back beyond that last jurist $\left({ }^{66}\right)$.

Thus, throughout the classical period, acceptilatio lost one by one the features it had had as a release on performance and which it should have retained so long as it was a fictitious payment $\left({ }^{67}\right)$. Eventually, indeed, it could be shown ex facie the acceptilatio that there had been no performance. But perhaps even in Justinian's law one rule remained which showed that acceptilatio had once been release on performance or at least, a fiction of such. It is generally agreed $\left({ }^{68}\right)$ rightly, that where there was acceptilatio of a conditional debt, the acceptilatio did not take effect unless and until the condition were realised. In this it resembles novatio of a conditional obligation. The texts do not really tell us much about the practical effects of this rule, but drawing an analogy from novatio it is argued that if the debtor died or were deported, pendente condicione, his heir or other successor would be liable for the debt $\left({ }^{69}\right)$. This, however, does not really explain the rule. The reason for it cannot be that the creditor wishes to release the debtor, but not, if he dies or is deported, his successor. If this were the creditor's intention, it would be both much simpler and more effective for him to do nothing and if the condition were fulfilled during the debtor's lifetime, simply to neglect exacting the debt for the time being. Nor can the reason be the maxim sometimes cited in connection with novatio of a conditional obligation " inelegans est obligationem ad heredis persona incipere") since accepti-

(66) Other texts a re D. 39.6.35.6 (Paul) ; 35.2.82 (Ulpian). Cf. Amelotri, op. cit., pp. 179-187 ; Srmonics, 'Die Donatio mortis causa im klassischen römischen Recht', Basle 1958, pp. 270-272.

(67) There are a few other texts not discussed above which show to a greater or less extent that the fiction was breaking down in a particular field ; D. $46.3 .71 .2 ; 46.3 .10 ; 32.3$ pr. ; $46.3 .71 .2 ; 12.4 .4$.

(68) E.g. Bohácec, 'Annali Palermo' 11 (1924), pp. 379-384; Solazzi, op. cit., p. 253 ; Bonifacio, 'La Novazione nel diritto romano', Naples 1950 , pp. $80-81$ : The texts are D. $46.3 .16 ; 46.4 .12 ; 46.4 .21$.

(69) BOHÄCE, op. cit., 1. 381. 
latio operated to extinguish an obligation and, if it took effect at once would, of course, terminate the obligation during the lifetime of the parties. The only text which discusses the consequences of the rule shows how absurd they could be.

D. 46.4.13.6. (Clpian 50 ad Sab.) Si Stichum aut decem sub condicione stipulatus Stichum acceptum fecerit et pendente condicione stichus decesserit, decem in obligatione manebunt, perinde ac si acceptilatio interposita non fuisset.

IIere the intention of the parties would seem clearly to have been to wipe out the obligation. I suggest that the rule dates back to the time when acceptilatio was a real payment. If then the debt were paid and acceptilatio made, pendente condicione, the debtor would be given a condictio against the creditor on account of indebiti solutio $\left({ }^{70}\right)$. And the rule remained even after acceptilatio ceased in other respects to be a fiction, perhaps because the reason for the rule, which can never have been very important, was not obvious.

(70) Cf. D. 12.6.16,17.18, ctc. 